\title{
Is multiculturalism in Russia possible? Intercultural relations in North Ossetia-Alania
}

\author{
Victoria N. Galyapina, Nadezhda M. Lebedeva* \\ International Scientific-Educational Laboratory for Socio-Cultural Research, National Research \\ University Higher School of Economics, Moscow, Russia
}

${ }^{\star}$ Corresponding author. E-mail: lebedhope@yandex.ru

\begin{abstract}
This article examines intercultural relations in the Republic of North Ossetia-Alania (RNO-A). The research is based on the theory of acculturation of J. Berry and uses the hypotheses and measures developed in the Mutual Intercultural Relations in Plural Societies project. The RNO-A is the most favorable place for Russians living in the North Caucasus because attitudes toward the Russian minority in the RNO-A are not discriminatory. Our goal was to test three hypotheses in the RNO-A: the multiculturalism hypothesis, the integration hypothesis, and the contact hypothesis. We conducted a sociopsychological survey. The sample included members of the ethnic majority, the Ossetians $(N=318)$, and members of the ethnic minority, the Russians $(N=327)$. Data processing was carried out using structural equation modeling (SEM) separately for the ethnic minority and for the ethnic majority, and the models were compared with each other. The results show that perceived security among the Russians (the ethnic minority) as well as among the Ossetians (the ethnic majority) promoted support for a multicultural ideology, tolerance, and mutual integration. The number and frequency of friendly intercultural contacts had a positive and significant impact on a preference for integration among both the Ossetians and the Russians. An integration strategy and the expectation of integration promoted life satisfaction in both groups. Because the results of the study confirmed all three hypotheses, we conclude that interethnic relations between the Russians and the Ossetians in the RNO-A are based on the principles of multiculturalism.
\end{abstract}

Keywords: intercultural relations, acculturation, ethnic majority, ethnic minority, multiculturalism, intercultural contact, integration

\section{Introduction}

A major challenge confronting Russian society in the 21 st century is finding effective strategies for managing cultural diversity. Researchers have discerned some basic principles that underpin the processes and outcomes of intercultural relations in plural societies. In our survey we used three hypotheses of intercultural relations 
offered by Berry (2013): the multiculturalism hypothesis, the contact hypothesis, and the integration hypothesis.

The basic notion of the multiculturalism hypothesis is that only when people are secure in their identities they will be in a position to accept those who differ from them. Conversely, when people feel threatened, they will develop prejudice and engage in discrimination. The multiculturalism hypothesis is confirmed in many studies. For example, in two national surveys in Canada (reviewed by Berry \& Kalin, 2000), measures of cultural security/threat and economic security/threat were created with respect to extant diversity and the continuing flow of immigration. These two security scores were correlated with each other and with various intercultural attitudes. Cultural security was negatively correlated with ethnocentrism and positively correlated with multicultural ideology and with the perceived consequences of multiculturalism. Economic security had a similar pattern of correlations with these variables.

Ward and Masgoret (2008) found that more frequent intercultural contact led to decreased intergroup anxiety, which, in turn, predicted lower perceptions of threat and more positive attitudes toward immigrants in New Zealand. A study of Estonian Russians showed that the high perception among Estonians that Russia presents a threat is an obstacle to the adaptation of Russians in Estonia (Kruusvall, Vetik, \& Berry, 2009).

Rohmann, Florack, and Piontkowski (2006) examined acculturation preferences and desired intergroup contact in connection with the Integrated Threat Theory. They found that the same threats - culture discordance and contact discordance - predicted both negative attitudes toward minority groups (Italians and Turks) among German hosts and negative attitudes toward the majority group (Germans) among immigrants. Moreover, the effects were stronger among and toward Turks than among and toward Italians. A study in the Netherlands (Van Oudenhoven, Groenewoud, \& Hewstone, 1996) showed that a secure attachment style was related to a preference for integration in both immigrants and the Dutch. In Russia, Lebedeva and Tatarko (2013) studied intercultural relations between migrants from the Caucasus and Muscovites. They found that cultural security predicted tolerance, a preference for integration, and social equality in both groups, but to a lesser extent among the Muscovites.

The contact hypothesis suggests that negative attitudes held by one group toward another are caused by a lack of knowledge about that group. When individuals of two groups come into positive, personal, and cooperative contact with each other, they will get to know each other, and doing so leads to the elimination or reduction of prejudice. However, there are two important conditions: there must be (1) equal status of individuals or groups in contact and (2) support for intercultural contact by the society. Under these conditions mutual attitudes and interactions will become increasingly positive - for instance, through a growing recognition of similarities (Allport, 1954; Pettigrew, 1997).

A good deal of research has been carried out to test this hypothesis (e.g., Pettigrew \& Tropp 2011; Van Oudenhoven et al., 1996). An example of the application of the contact hypothesis to the migration context can be found in Voci and Hewstone (2003) in an Italian study and by Van Oudenhoven and colleagues (1996) in Dutch 
research; both studies demonstrated that intercultural contact significantly improved attitudes toward immigrants.

In addition, an analysis of the research showed that cross-ethnic friendships are positively related to social competence and life satisfaction (e.g., Feddes, Noack, \& Rutland, 2009; Hui, Chen, Leung, \& Berry, 2015; Hunter \& Elias, 1999; Lease \& Blake, 2005; Tropp \& Prenovost, 2008). Research with young adults suggests that cross-ethnic friendships are related to psychological well-being (Mendoza-Denton \& Page-Gould, 2008). For children living in multiethnic contexts cross-ethnic friendships have a protective role in psychological well-being (Bagci, Rutland, $\mathrm{Ku}$ mashiro, Smith, \& Blumberg, 2014).

The integration hypothesis posits that when individuals are engaged in both cultures (their own heritage culture and that of the larger society), they will achieve a higher level of adaptation and well-being than when they engage in only one or neither culture. The evidence for integration being associated with better adaptation has been reviewed by Berry $(1997,2011)$. More recently, Nguyen and BenetMartínez (2013) carried out a meta-analysis across 83 studies with over 20,000 participants. They found that integration had a significant and positive relationship with both psychological adaptation (e.g., life satisfaction, positive affect, selfesteem) and sociocultural adaptation (e.g., academic achievement, career success, social skills, lack of behavioral problems).

Ward and Kennedy (1994) reported that, compared with assimilated sojourners, integrated sojourners experienced less psychological distress. Studies also showed that the integration expectation predicted both success in coping with stressful situations and emotional intelligence in dominant group members (Schmitz \& Berry, 2009). Verkuyten (2009) argued that acceptance and recognition of cultural diversity are important for self-feelings and showed that endorsement of multiculturalism is positively associated with self-esteem for individuals in both dominant and nondominant groups.

However, in some studies the importance of the strategy of assimilation in the adaptation of migrants and ethnic minorities has been demonstrated (JasinskajaLahti, Horenczyk, \& Kinunen, 2011; Kus-Harbord \& Ward, 2015; Ward \& RanaDeuba, 1999). For example, a study in Nepal showed that support for assimilation promotes better sociocultural adjustment, while support for integration promotes better psychological well-being (Ward \& Rana-Deuba, 1999).

\section{The context of interethnic relations in the Republic of North Ossetia-Alania}

One of the important issues in the RNO-A is interethnic relations and the strategies of mutual acculturation of the dominant ethnic group (Ossetians) and Russians as an ethnic minority. The role of Russians in the economic and social-cultural development of the RNO-A is significant. Russians had a dominant position in the political, economic, cultural, and educational fields through the 1980s. In the 1990s Russians were forced out of their positions and replaced by members of the dominant ethnic group. Analysis of the dynamics of the ethnic composition of the population of the RNO-A suggests an intensive outflow of the Russian population 
(Itogi . . . 2002, 2004; Itogi . . 2010, 2012; Vsesoyuznaya, 2015). Russians constituted around $50 \%$ of the population of Ossetia in the 1940s to the 1970 s, about $30 \%$ in the 1970 s to the 1990 s, and $20 \%$ in 2010 . Because of such changes the identity of Russians living in the RNO-A is being transformed; they have started to recognize themselves as an ethnic minority (Belozerov, 2001; Soldatova, 1998; Vorobyov, 2001), although they are still the majority in Russia as a whole.

Nevertheless, the literature shows (Migratsiya russikikh, 2013) that attitudes toward the Russian minority in the RNO-A are not discriminatory and that the Republic is the most favorable place for Russians in the North Caucasus. Studies have found that some factors contribute to sociopolitical stability and intergroup peace in the RNO-A: positive historical memories, the long experience of living together in the area, the use of the Russian language in interethnic communication, and the fact that Ossetians and Russians belong to the same Orthodox Church in the RNO-A (Balikoev, 2011).

However, because of the hierarchical structure of Ossetian society, the incorporation of Russians into the regional political and business elites is difficult. Social stratification contributes to the formation of various sectors of society along ethnic lines. Thus, ethnic Ossetians dominate in the parliament (Dzadziev, 2008). Research on strategies of intercultural interaction (Gutsunarova, 2010) have shown that the majority of Ossetians and Russians living in the RNO-A choose a strategy of equal-status interaction and that these ethnic groups are oriented toward mutual integration (Kobakhidze, 2005). However, Russians prefer equal status in interpersonal communication more than Ossetians do (Gutsunarova, 2010). This preference is especially evident in business (Kobakhidze, 2005): Russians, more than Ossetians, are open to joint activities (Gurieva, 1997, 2010).

Ossetians have a high degree of emotional acceptance of Russians (Gurieva, 1997, 2010), and, in general, they have positive stereotypes of Russians. However, Ossetians more frequently demonstrate isolationist attitudes, they have a dominant orientation toward monoethnic marriages, and they are less ready to accept a person from another ethnic group as a supervisor (Kobakhidze, 2005).

The literature and the descriptions of social context allow us to define the purpose of our study and to formulate research hypotheses.

\section{The research hypotheses}

The objective of our research was to test in the RNO-A three hypotheses of intercultural relations: the multiculturalism hypothesis, the contact hypothesis, and the integration hypothesis.

1. The multiculturalism hypothesis: The higher one's sense of security, the higher is one's willingness to accept those who are culturally different. Specifically:

1a. The higher the perceived security, the higher are support for multicultural ideology and ethnic tolerance for both the Russian minority and the majority group.

1b. The higher the perceived security, the higher is support for the integration strategy/expectation and the lower is support for the assimilation strategy/ expectation for both the Russian minority and the majority group. 
2. The contact hypothesis: Intercultural contact promotes mutual acceptance (under certain conditions, especially that of equality). Specifically:

$2 a$. The higher the intensity of friendly contacts with the majority group members among the Russian minority group members, the higher are their level of tolerance and their preference for integration and assimilation expectations.

2b. The higher the intensity of friendly contacts with the Russian minoritygroup members among the majority group members, the higher are their level of tolerance and their preference for integration and assimilation strategies.

2c. The higher the intensity of friendly contacts with the majority group members among the Russian minority group members, the higher are the level of life satisfaction, self-esteem, and sociocultural adaptation of the members of the Russian minority group and the higher are the level of life satisfaction and self-esteem of the members of the majority group.

3. The integration hypothesis: Those who prefer the integration strategy have greater psychological and sociocultural adaptation. Specifically:

3a. The higher the preference for the acculturation strategy of integration among members of the Russian minority group, the higher is their level of life satisfaction and self-esteem; the higher their preference for the acculturation strategy of assimilation, the better is their sociocultural adaptation.

$3 \mathrm{~b}$. The higher the acculturation expectations of integration among members of the majority group, the higher are their level of life satisfaction and their self-esteem.

\section{Method}

\section{Participants}

The study was conducted in the RNO-A in 2014. The sample included members of the ethnic majority, the Ossetians $(N=318)$, and of the ethnic minority, the Russians $(N=327)$. Table 1 provides the basic characteristics of these samples.

Table 1. Gender and age characteristics of the sample

\begin{tabular}{cccccccc}
\hline \multirow{2}{*}{ Respondents } & \multirow{2}{*}{$\boldsymbol{N}$} & \multicolumn{3}{c}{ Gender characteristics } & \multicolumn{3}{c}{ Age characteristics } \\
\cline { 3 - 8 } & & Male $(N, \%)$ & Female $(N, \%)$ & Min. & Max. & $M$ & $S D$ \\
\hline \multirow{2}{*}{ Russians } & 327 & $99(30 \%)$ & $228(70 \%)$ & 15 & 91 & 44.2 & 21.8 \\
Ossetians & 318 & $97(31 \%)$ & $221(69 \%)$ & 15 & 87 & 44.2 & 22.5 \\
\hline
\end{tabular}

\section{Measures}

The study used scales from the Mutual Intercultural Relations in Plural Societies questionnaire (http://www.victoria.ac.nz/cacr/research/mirips), translated into 
Russian and adapted for use in Russia (Lebedeva, 2009). The following scales (except for the Contact scale) were tested using confirmatory factor analyses (CFA). Indicators of all models meet recommended characteristics (Hu \& Bentler, 1999).

Contact. Two items: "How many close Ossetian [Russian] friends do you have?" "How often do you meet with close Ossetian [Russian] friends?" (for Russians, $\alpha=.77$; for Ossetians, $\alpha=.72$ ).

Perceived security. Three items: for example, "There is room for a variety of languages and cultures in Ossetia."

Multicultural ideology. Five items: for example, "We should recognize that cultural diversity is a fundamental characteristic of Ossetian society."

Tolerance. Three items: for example, "We should promote equality among all groups, regardless of racial or ethnic origin."

Acculturation strategies (for the Russian minority). Integration: Three items: for example, "It is important to me to be fluent in both Ossetian and Russian." Assimilation: Four items: for example, "I prefer social activities that involve Ossetians only."

Acculturation expectations (for the Ossetian majority). Integration: Three items: for example, "Russians should be fluent in both Ossetian and Russian." Assimilation: Four items: for example, "Russians should prefer social activities that involve only Ossetians." self."

Self-esteem. Four items: for example, "On the whole, I am satisfied with my-

Life satisfaction. Four items: for example, "In most ways my life is close to my ideal."

Sociocultural adaptation (for the Russian minority). Seven items: for example, "Living in Ossetia, how much difficulty do you experience in relating to members of the opposite sex?"

Sociodemographic data. We asked our participants about their personal characteristics (gender, age, education, and ethnicity).

\section{Procedure}

We used the snowball technique for sampling. We asked Ossetian and Russian university and high school students to fill out questionnaires by themselves as well as to distribute them among their parents and grandparents. Respondents were not remunerated.

\section{Data processing}

We used the following methods of data processing: descriptive statistics, Cronbach's $\alpha$, confirmatory factor analyses, structural equation modeling (SEM) with SPSS 22.0 and AMOS 22.0.

\section{Results}

Table 2 presents means, standard deviations, and $t$-tests of all the measures obtained from the samples of Ossetians and Russians in the RNO-A. Perceived security, multicultural ideology, tolerance, the acculturation strategy of integration, 
Table 2. Means, standard deviations, and $t$-tests for the variables measured

\begin{tabular}{lcccccc}
\hline \multirow{2}{*}{ Name of the scale } & \multicolumn{2}{c}{ Russians } & \multicolumn{2}{c}{ Ossetians } & \multirow{2}{*}{ t } \\
\cline { 2 - 5 } & $\mathbf{M}$ & SD & M & SD & \\
\hline Perceived security & 4.11 & .99 & 4.04 & 1.00 & .859 \\
Intercultural friendships/contacts & 3.62 & 1.00 & 4.15 & .92 & $7.00^{* * *}$ \\
Multicultural ideology & 3.99 & .78 & 3.85 & .74 & $2.25^{*}$ \\
Tolerance & 4.11 & .92 & 3.93 & .83 & $3.15^{* *}$ \\
Integration & 4.05 & .94 & 3.93 & .94 & 1.47 \\
Assimilation & 1.81 & .85 & 2.04 & .95 & $3.33^{* * *}$ \\
Self-esteem & 4.07 & .72 & 3.92 & .85 & $2.43^{* *}$ \\
Life satisfaction & 3.23 & .87 & 3.39 & .88 & $2.32^{*}$ \\
Sociocultural adaptation & 2.16 & .91 & & & \\
\hline
\end{tabular}

${ }^{*} p<.05,{ }^{* *} p<.01,{ }^{* * *} p<.001$

and self-esteem were significantly higher among the Russians, while the Ossetians' scores were higher on intensity of friendly contacts with the Russians, the acculturation expectation of assimilation, and life satisfaction. There were significant differences on all measures except perceived security and integration, which were approximately equal in both the groups. The Ossetians' preference for assimilation of the Russians was expressed by their higher score on the expectation of assimilation of Russians, who preferred assimilation to a lesser extent. The comparisons of acculturation expectations and strategies need to be treated with caution because of the different phrasing of the questions.

Figure 1 presents the results of the testing of the three hypotheses of intercultural relations among the Ossetians.

Consistent with the multiculturalism hypothesis, the levels of support for multicultural ideology and tolerance among the Ossetians could be predicted by their perceived security (.44 and .32 respectively). In addition, perceived security among the Ossetians positively and significantly affected their acculturation expectation of integration (.49) but had a negative and significant effect on their acculturation expectation of assimilation (-.33). In other words, the multiculturalism hypothesis was fully supported in the sample of Ossetians.

The contact hypothesis was partially supported within the majority group. Among the Ossetians their friendly contacts with Russians positively and significantly affected their acculturation expectation of integration (.17) but not their preference for assimilation (.05) and ethnic tolerance (.02). In addition, the relationship between their contacts with Russian friends and perceived security was not significant $(-.01)$.

Complementing the contact hypothesis, our proposal was that intense intercultural contacts as well as the acculturation expectation of integration would promote more life satisfaction and higher self-esteem. However, the results did not confirm our prediction: the Ossetians' friendly contacts with Russians did not promote 


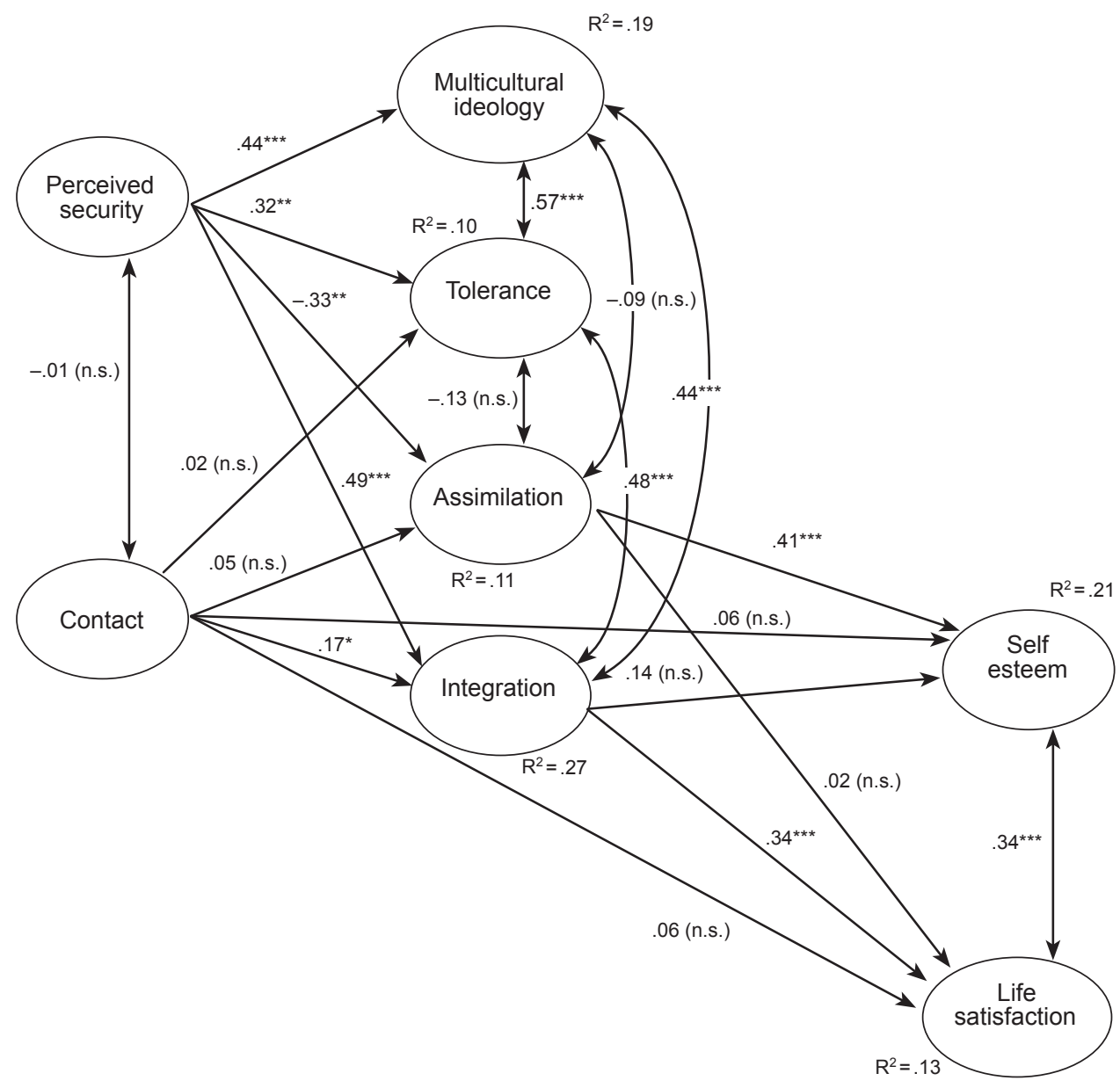

Figure 1. Results of SEM for the three hypotheses of intercultural relations for the Ossetians. ${ }^{*} p<.05,{ }^{* *} p<.01,{ }^{* *} p<.001$, n.s. - not significant. Indicators of the model: $\chi^{2}=682.2 ; d f=292$; $p=.000 ; \chi^{2} / d f=2.3 ; \mathrm{CFI}=.98 ; \mathrm{RMSEA}=.065 ; \mathrm{SRMR}=.066$; PCLOSE $=.013$.

their life satisfaction and self-esteem (.06 and .06), which, however, were positively associated each with other (.34).

Consistent with the integration hypothesis, a preference for the integration expectation among the Ossetians had a positive impact on their life satisfaction (.34); however, the relationship with self-esteem, while positive, was not significant (.14). Their acculturation expectation of assimilation had an insignificant relationship with life satisfaction (.02) but had a significant and positive impact on their selfesteem (.41).

We revealed additional relationships in this model: the level of tolerance among the Ossetians was positively and significantly related to their level of support for multicultural ideology (. 57) and to their acculturation expectation of integration (.48), but there was no such significant relationship for the acculturation expecta- 
tion of assimilation (-.13). Support for multicultural ideology was significantly and positively correlated with the expectation of integration (.44); however, this support was not significant for the expectation of assimilation (-.09).

Figure 2 presents the results of the testing of the three hypotheses of intercultural relations among Russians in the RNO-A.

For the Russians, the multiculturalism hypothesis was also fully supported: perceived security predicted tolerance (.25) and multicultural ideology (.78). In addition, perceived security among the Russians, as well as among the Ossetians,

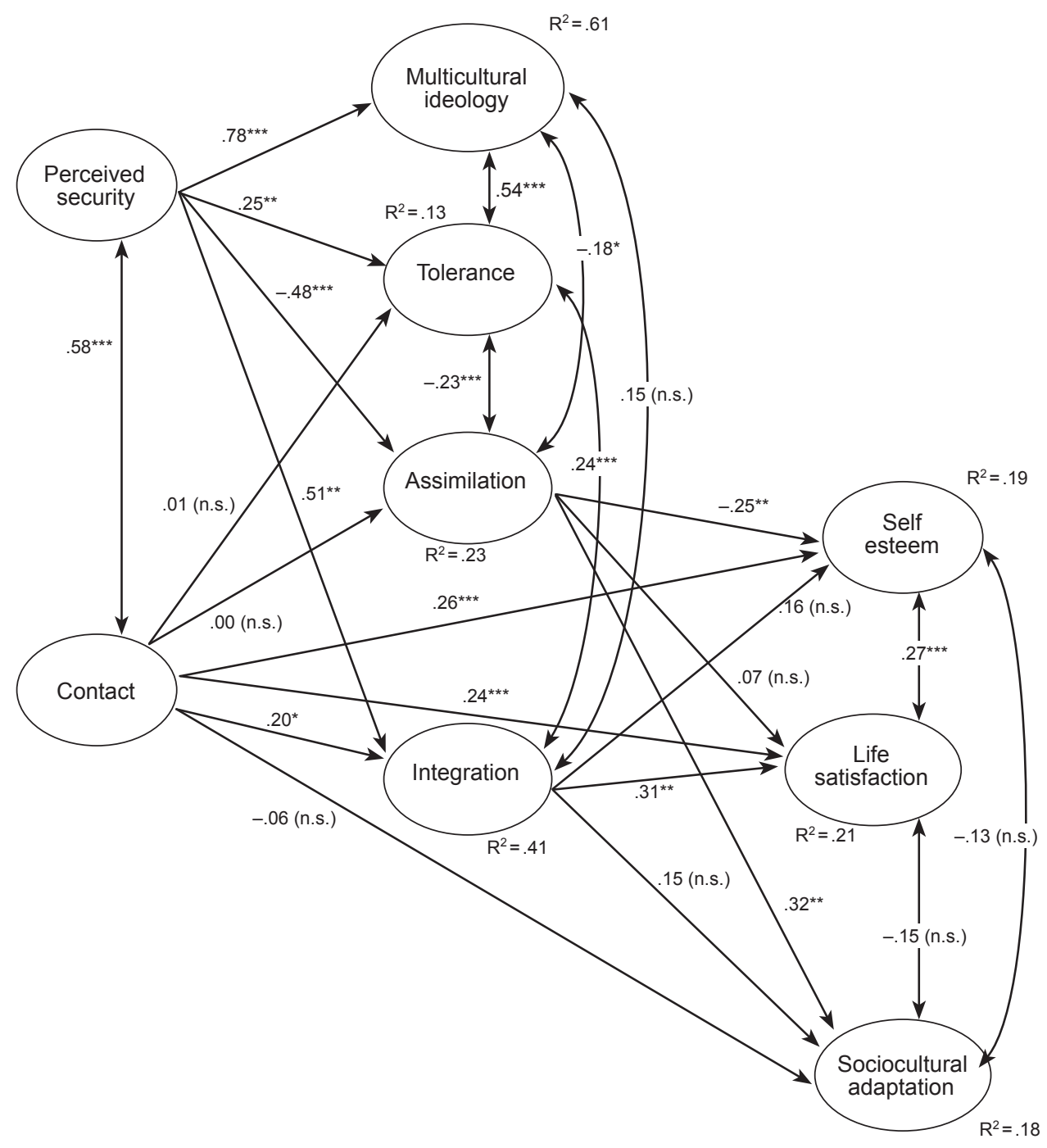

Figure 2. Results of SEM for the three hypotheses of intercultural relations for Russians. ${ }^{\star} p<.05,{ }^{* *} p<.01,{ }^{* * *} p<.001$, n.s. - not significant. Indicators of the model: $\chi^{2}=1014.6$; $d f=497 ; p=.000 ; \chi^{2} / d f=2.0 ; \mathrm{CFI}=.91 ; \mathrm{RMSEA}=.057 ; \mathrm{SRMR}=.062 ; \mathrm{PCLOSE}=.016$. 
positively and significantly affected their acculturation expectation of integration (.51) but had a negative and significant effect on their acculturation expectation of assimilation (-.48).

The contact hypothesis was partially supported within the Russian minority: their friendly contacts with Ossetians positively and significantly affected the acculturation strategy of integration (.20) but not their preference for assimilation $(.00)$ or ethnic tolerance (.01). However, the Russians' friendly contacts with Ossetians had a significant and positive association with their perceived security (.58), in contrast to the Ossetians' experiences.

In addition, the Russians' friendly contacts with Ossetians promoted higher life satisfaction (.24) and self-esteem (.26), in contrast to the Ossetians' experiences. However, intercultural friendships did not affect the sociocultural adaptation of the Russians (-.06).

Consistent with the integration hypothesis, a preference for the integration strategy among the Russians had a significant positive impact on their life satisfaction (.31). The relationship between the acculturation strategy of integration and self-esteem, while positive, was not significant (.16). The impact of integration on sociocultural adaptation was negative but not significant (-.15). Among the Russians, their acculturation strategy of assimilation had a significant and positive impact on their sociocultural adaptation (.32) and a significant negative impact on their self-esteem $(-.25)$. However, assimilation had no significant effect on their life satisfaction (.07).

The level of tolerance among the Russians was positively and significantly related to their level of support for multicultural ideology (.54) and to the acculturation strategy of integration (.24), but there was a negative and significant relationship with the acculturation strategy of assimilation (-.23). Support for multicultural ideology had a positive but insignificant correlation with the strategy of integration (.15), but there was a negative and significant relationship with the acculturation strategy of assimilation (-.18).

As with the Ossetians, the Russians' self-esteem was positively associated with their life satisfaction (.27). The relationship of life satisfaction and self-esteem with sociocultural adaptation was insignificant and negative (-.15 and -.13 , respectively).

Overall, the three hypotheses showed the same pattern of relationships in both the Russian and the Ossetian cultural groups: intercultural contacts promoted a preference for the integration strategy and expectation; perceived security predicted tolerance and multicultural ideology. Intercultural contacts also promoted a preference for the acculturation strategy and the expectation of integration, which in its turn promoted better life satisfaction.

However, we also found differences in the relationships in the models for the Russians and the Ossetians. For the Russians, the acculturation strategy of assimilation affected their self-esteem negatively, but for the Ossetians this influence was positive. For the Russians, their friendly contacts with Ossetians promoted higher life satisfaction and self-esteem, but this relationship was insignificant for the Ossetians. In addition, the results demonstrated that, among the Russians, intercultural friendly contacts had a positive and significant relationship with their perceived security, but this relationship was insignificant for the Ossetians. 
Overall, the findings of this study are generally consistent with the three hypotheses. The multiculturalism hypothesis received full support among the Ossetians (the ethnic majority) and the Russians (the ethnic minority). Perceived security predicted multicultural ideology and tolerance in both samples. These results are consistent with data obtained in other countries (e.g., Berry, 2006): measures of security correlated positively with positive intercultural attitudes and multicultural ideology.

Perceived security played an important role in the preference for integration and assimilation. For the ethnic majority and minority members in the RNO-A, perceived security promoted a preference for the acculturation strategy and the expectation of integration but did not promote the acculturation strategy and the expectation of assimilation. In other words, the Ossetians and the Russians, who had a strong mutual perceived security, preferred the integration but not the assimilation strategy or expectation.

The contact hypothesis received partial confirmation in both samples. The results of our study demonstrated that intercultural friendly contacts predicted a preference for integration but did not predict a preference for assimilation or tolerance. The Ossetians were willing to accept Russians on their own cultural terms and did not require them to give up their cultural heritage in order to be accepted in the larger society. Having friends among Ossetians and frequency of contacts with them promoted the orientation of the Russians to the integration strategy. These data partly confirm the results obtained earlier in the RNO-A by Gutsunarova (2010), who notes that intercultural contacts significantly and positively correlated with positive attitudes toward integration.

In addition to orientation to the integration hypothesis, intercultural friendly contacts of ethnic minority group members in the RNO-A promoted both their life satisfaction and their self-esteem; however, for ethnic majority group members, this effect was not significant. Similar evidence, obtained in several other studies, has shown that among children and young adults, cross-ethnic friendships are related to psychological well-being (e.g., Bagci et al., 2014; Mendoza-Denton \& PageGould, 2008). In general, for the Russians, both the preference for the integration strategy and intercultural friendly contacts played an important role in obtaining life satisfaction, whereas for the Ossetians only the integration expectation promoted their life satisfaction.

We also found that, for the Russians, intercultural friendships were significantly and positively related to their perceived security, whereas for the Ossetians, this relationship was insignificant. Our data differ from the results of some other studies. For example, Lebedeva and Tatarko (2013) showed that, for migrants, perceived security and contacts were not related to each other. In other words, to have friendly intercultural contacts, a person need not always feel secure.

Consistent with the integration hypothesis, support for the integration strategy among the Russians and the integration expectation among the Ossetians predicted only their life satisfaction. In part, our results are consistent with other research (Ward \& Kennedy, 1994) reporting that, compared with assimilated sojourners, integrated sojourners experienced less psychological distress. Previous studies have also shown that the integration expectation predicts both successful 
coping in stressful situations and emotional intelligence in dominant group members (Schmitz \& Berry, 2009). Jasinskaja-Lahti and colleagues (2011) found in Finland that the integration attitude positively predicted the psychological adaptation of immigrants from Russia and the former Soviet Union. Hui and colleagues (2015) showed that, for dominant-group members in Hong Kong, the integration expectation predicted their psychological adaptation. However, the impact of integration on self-esteem was not revealed in our research data, which were different from data obtained by Verkuyten (2009), who showed that endorsement of multiculturalism is positively associated with self-esteem for individuals of both dominant and nondominant groups.

For ethnic majority-group members in the RNO-A, the assimilation expectation positively predicted their self-esteem, while for ethnic minority-group members, the assimilation strategy negatively predicted their self-esteem. The reason may be that, among Russians, refusing to maintain one's own cultural heritage is not relevant to feelings of self-esteem in a multicultural society like the RNO-A. Our results are consistent with data obtained by Kus-Harbord and Ward (2015) in a study of ethnic Russians in Estonia. Other researchers (Kolosov \& O'Loughlin, 2008 ) have found that assimilation is associated with higher well-being under conditions of low perceived group devaluation but with poorer well-being when group devaluation is perceived as high. Our results may imply that the Russians had a higher perceived group devaluation; therefore, support for the strategy of assimilation negatively correlated with self-esteem. In contrast, the Ossetians may have had a lower perceived group devaluation, and thus support for the strategy of assimilation positively correlated with self-esteem.

In contrast to studies that report that the strategy of integration is most conducive to the sociocultural adaptation of nondominant groups (Berry, 1997; Nguyen \& Benet-Martínez, 2013; Sam \& Berry, 2006), we found that among the Russians only the assimilation strategy positively predicted sociocultural adaptation. These data are consistent with the results of Ward and Kennedy (1994), who noted that integrated and assimilated sojourners encountered less social difficulty, and with the results of Ward and Rana-Deuba (1999), who noted that integration promoted better psychological well-being, while assimilation promoted better sociocultural adjustment.

For both samples we found that tolerance significantly and positively correlated with multicultural ideology and a preference for integration. The Russians and the Ossetians who recognized intergroup differences and respected equal rights and who held a positive attitude toward multiculturalism preferred the integration strategy/expectation. Similar results have been found in studies of dominant and nondominant groups in Hong Kong (Hui et al., 2015) and in a study of Dutch majority-group members (Schalk-Soekar \& Van de Vijver, 2008).

In addition, for the Ossetians multicultural ideology was significantly and positively related to the acculturation expectation of integration. However, for the Russians this relationship was not significant. For the Russians multicultural ideology and tolerance were significantly and negatively related to the acculturation strategy of assimilation (for ethnic majority-group members these relationships were not significant). 
Our study showed that in both samples self-esteem was significantly and positively correlated with life satisfaction. For the Russians self-esteem and life satisfaction had negative relationships with sociocultural adaptation, but these relationships were not significant.

\section{Conclusion}

We have shown that a sense of security is important in achieving mutual acceptance and integration among ethnic minority and majority groups in the RNO-A: in both samples, security was strongly related to multicultural ideology and tolerance. Therefore, the multiculturalism hypothesis received full support with both the Ossetians and the Russians. In addition, we found that perceived security predicted positively the integration strategy/expectation and predicted negatively the assimilation strategy/expectation.

The present study proved that the quantity of interethnic friends and the frequency of meeting with them promoted the integration strategy/expectation but not the assimilation strategy/expectation and tolerance in both samples. In addition, we found that for the ethnic minority group in the RNO-A intercultural contacts can be antecedents of higher life satisfaction and self-esteem. Thus, the contact hypothesis was partially supported in our study. In addition, intercultural contacts correlated significantly and positively with perceived security in the ethnic minority group.

The integration hypothesis was also partially supported: the Russians' preference for the integration strategy promoted their life satisfaction but not their selfesteem and better sociocultural adaptation. The Ossetians' preference for the integration expectation also promoted their life satisfaction but not their self-esteem. In addition, we found that support for the acculturation strategy of assimilation significantly and negatively predicted self-esteem and significantly and positively predicted better sociocultural adaptation in the ethnic minority group. For the ethnic majority group, support for the acculturation expectation of assimilation significantly and positively predicted their self-esteem.

Therefore, our testing of the multiculturalism hypothesis, the integration hypothesis, and the contact hypothesis in the RNO-A showed that, in general, mutual intercultural attitudes are positive and correspond to the ideology of multiculturalism in the RNO-A. This identified pattern of relations demonstrates that intergroup interaction in a multicultural society between two ethnic groups that are both oriented toward mutual integration and close intercultural contacts promotes the psychological well-being of both groups.

\section{Limitations}

The main limitation of this study is that it was conducted in a specific region. This study did not measure variables that may be important for studies of acculturation and intercultural relations in other regions - for example, cultural distance. In the RNO-A the cultural distance between Russians and Ossetians tends to be rather small because Ossetians and Russians are both Orthodox Christians, in contrast 
to the situation in other regions of the North Caucasus. The cultural specificity of this region might have an impact on the positive nature of intercultural relations in it. In future research, it will be important to test these hypotheses in regions with a greater cultural distance between the majority and minority groups.

\section{Acknowledgments}

This work was supported by the Russian Science Foundation (project № 15-1800029).

\section{References}

Allport, G. W. (1954). The nature of prejudice. Reading, MA: Addison-Wesley.

Bagci, S. C., Rutland, A., Kumashiro, M., Smith, P. K., \& Blumberg, H. (2014). Are minority status children's cross-ethnic friendships beneficial in a multiethnic context? British Journal of Developmental Psychology, 32, 107-115. doi: 10.1111/bjdp.12028

Balikoev, A. T. (2011). Problemy mezhnatsional'nykh otnosheniy v Severnoy Osetii i mekhanizm $i k h$ regulirovaniya (1991-2011 gg.) [The problems of interethnic relations in North Ossetia and a mechanism for their regulation (1991-2011)] (Unpublished doctoral dissertation). Vladikavkaz, Republic of North Ossetia-Alania: North Ossetian State University.

Belozerov, V. S. (2001). Russkiye na Kavkaze: Evolyutsiya rasseleniya [Russians in the Caucasus: The evolution of settlement]. In V. V. Chernous (Ed.), Russkiye na Severnom Kavkaze: Vyzovy XXI veka, sbornik nauchnykh statey [Russians in the North Caucasus: The challenges of the XXI century, collection of scientific articles.] Rostov-on-Don, Russia: SKNC VSH.

Berry, J. W. (1997). Immigration, acculturation and adaptation. Applied Psychology. An International Review, 46(1), 5-68. doi: 10.1111/j.1464-0597.1997.tb01087.x

Berry, J. W. (2006). Mutual attitudes among immigrants and ethnocultural groups in Canada. International Journal of Intercultural Relations, 30(6), 719-734. doi: 10.1016/j. ijintrel.2006.06.004

Berry, J. W. (2011). Immigrant acculturation: Psychological and social adaptations. In A. Assaad (Ed.), Identity and political participation (pp. 279-295). London: Wiley.

Berry, J. W. (2013). Research on multiculturalism in Canada. International Journal of Intercultural Relations, 37(6), 663-675. doi: 10.1016/j.ijintrel.2013.09.005

Berry, J. W., \& Kalin, R. (2000). Multicultural policy and social psychology: The Canadian experience. In S. A. Renshon \& J. Duckitt (Eds.), Political psychology: Cultural and cross-cultural foundations (pp. 263-284). New York: Macmillan.

Dzadziev, A. B. (2008). Russkoye naseleniye respublik Severnogo Kavkaza: Faktory vynuzhdennoy migratsii Severnyy Kavkaz: Profilaktika konfliktov [The Russian population of the North Caucasus republics: Factors of forced migration in the North Caucasus: The prevention of conflicts]. Moscow: Institute of Ethnology and Anthropology of Russian Academy of Sciences.

Feddes, A. R., Noack, P., \& Rutland, A. (2009). Direct and extended friendship effects on minority and majority children's interethnic attitudes: A longitudinal study. Child Development, 80, 377-390. doi: 10.1111/j.1467-8624.2009.01266.x

Gurieva, S. D. (1997). Etnosotsial'naya ustanovka v mezhnatsional'nykh otnosheniyakh [Ethnosocial setting in international relations] (Unpublished doctoral dissertation). St. Petersburg: St. Petersburg State University. 
Gurieva, S. D. (2010). Psikhologiya mezhetnicheskikh otnosheniy [The psychology of interethnic relations]. St. Petersburg: VVM.

Gutsunarova, S. V. (2010). Strategii mezhetnicheskogo vzaimodeystviya osetin i russkikh, prozhivayushchikh $v$ respublike Severnaya Osetiya-Alaniya [Strategies of interethnic interaction and Russian Ossetians living in the Republic of North Ossetia-Alania]. (Unpublished doctoral dissertation). St. Petersburg: St. Petersburg State University.

Hu, L. T., \& Bentler, P. M. (1999). Cutoff criteria for fit indexes in covariance structure analysis: Conventional criteria versus new alternatives. Structural Equation Modeling, 6(1), 1-55. doi: 10.1080/10705519909540118

Hui, B.P.H., Chen, S. X., Leung, C. M., \& Berry, J. W. (2015). Facilitating adaptation and intercultural contact: The role of integration and multicultural ideology in dominant and nondominant groups. International Journal of Intercultural Relations, 45, 70-84. doi: 10.1016/j. ijintrel.2015.01.002

Hunter L., \& Elias, M. J. (1999). Interracial friendships, multicultural sensitivity, and social competence: How are they related? Journal of Applied Developmental Psychology, 20, 551-573. doi: 10.1016/S0193-3973(99)00028-3

Itogi vserossiyskoy perepisi naseleniya 2002 (2004). [The results of the National Population Census of 2002] (vol. 4, book 1). Moscow: IPC Statistics of Russia.

Itogi vserossiyskoy perepisi naseleniya 2010 (2012). [The results of the National Population Census of 2010] (vol. 11). Svodnyye itogi Vserossiyskoy perepisi naseleniya 2010 [Summary results of the national census in 2010]. Retrieved from http://www.gks.ru/free_doc/new_site/ perepis2010/croc/vol11pdf-m.html

Jasinskaja-Lahti, I., Horenczyk, G., \& Kinunen, T. (2011). Time and context in the relationship between acculturation attitudes and adaptation among Russian-speaking immigrants in Finland and Israel. Journal of Ethnic and Migration Studies, 37(9), 1423-1440. doi: 10.1080/1369183X.2011.623617

Kobakhidze, E. I. (2005). Integratsionnyye $i$ dezintegratsionnyye protsessy $v$ mezhetnicheskom vzaimodeystvii na Severnom Kavkaze (na primere RSO-A $i$ KBR) [Integration and disintegration processes in interethnic relations in the North Caucasus (the example of North Ossetia-Alania and the KBR)]. SOCIS, 2, 66-74.

Kolosov, V. A., \& O'Loughlin, J. (2008). Sotsial'no-territorial'naya dinamika i etnicheskiye otnosheniya na Severnom Kavkaze [Socio-territorial dynamics and ethnic relations in the North Caucasus]. Retrieved from http://www.civisbook.ru/files/File/Kolosov_2008_4.pdf

Kruusvall, J., Vetik, R., \& Berry, J. W. (2009). The strategies of inter-ethnic adaptation of Estonian Russians. Studies of Transition States and Societies, 1(1), 3-24.

Kus-Harbord, L., \& Ward, C. (2015). Ethnic Russians in post-Soviet Estonia: Perceived devaluation, acculturation, well-being, and ethnic attitudes. International Perspectives in Psychology: Research, Practice, Consultation, 4(1), 66-81. doi: 10.1037/ipp0000025

Lease, A. M., \& Blake, J. J. (2005). A comparison of majority-race children with and without a minority-race friend. Social Development, 14, 20-41. doi: 10.1111/j.1467-9507.2005.00289.x

Lebedeva, N. M. (2009). Teoreticheskiye podkhody k issledovaniyu vzaimnykh ustanovok i strategiy mezhkul'turnogo vzaimodeystviya migrantov i naseleniya Rossii [Theoretical approaches to the study of the mutual attitudes and strategies of intercultural interaction among migrants and the population of Russia]. In N. M. Lebedeva \& A. N. Tatarko (Eds.), Strategii mezhkul'turnogo vzaimodeystviya migrantov i naseleniya Rossii: Sbornik nauchnykh statey [Strategies for the intercultural interaction of migrants and the population in Russia: A collection of scientific articles] (pp. 10-63). Moscow: RUDN. 
Lebedeva, N. M., \& Tatarko, A. N. (2013). Immigration and intercultural interaction strategies in post-Soviet Russia. In E. Tartakovsky (Ed.), Immigration: Policies, challenges and impact (pp. 179-194). New York: Nova Science.

Mendoza-Denton, R., \& Page-Gould, E. (2008). Can cross-group friendships influence minority students' well-being at historically White universities? Psychological Science, 19, 933-939. doi: 10.1111/j.1467-9280.2008.02179.x

Migratsiya russkikh: Prichiny ottoka s Severnogo Kavkaza: Opisaniye problemy, aktual'naya situatsiya (1950-2013). (2013). [The migration of Russians: Causes of the outflow from the North Caucasus: Description of the problem, the current situation (1950-2013)]. Moscow. Retrieved from file:///C:/Users/Ace/Downloads/migratsiyarusskihdoklad.pdf

Nguyen, A.-M.T.D., \& Benet-Martínez, V. (2013). Biculturalism and adjustment: A meta-analysis. Journal of Cross-Cultural Psychology, 44(1), 122-159. doi: 10.1177/0022022111435097

Pettigrew, T. F. (1997). Generalized intergroup contact effects on prejudice. Personality and Social Psychology Bulletin, 23, 173-185. doi: 10.1177/0146167297232006

Pettigrew, T. F., \& Tropp, L. R. (2011). When groups meet. The dynamics of intergroup contact. New York: Psychology Press.

Rohmann, A., Florack, A., \& Piontkowski, U. (2006). The role of discordant acculturation attitudes in perceived threat: An analysis of host and immigrant attitudes in Germany. International Journal of Intercultural Relations, 30, 683-702. doi: 10.1016/j.ijintrel.2006.06.006

Sam, D. L., \& Berry, J. W. (Eds.). (2006). Handbook of acculturation psychology. Cambridge, U.K.: Cambridge University Press. doi: 10.1017/CBO9780511489891

Schalk-Soekar, S.R.G., \& Van de Vijver, F.J.R. (2008). The concept of multiculturalism: A study among Dutch majority members. Journal of Applied Psychology, 38(8), 2152-2178. doi: $10.1111 /$ j.1559-1816.2008.00385.x

Schmitz, P. G., \& Berry, J. W. (2009). Structure of acculturation attitudes and their relationships with personality and psychological adaptation: A study with immigrant and national samples in Germany. In K. Boehnke (Ed.), Proceedings of IACCP Congress. Bremen. Retrieved from Retrieved from https://publications.hse.ru/chapters/139814898

Soldatova, G. U. (1998). Psikhologiya mezhetnicheskoy napryazhennosti [The psychology of ethnic tension]. Moscow: Smysl.

Tropp, L. R., \& Prenovost, M. A. (2008). The role of intergroup contact in predicting children's inter-ethnic attitudes: Evidence from meta-analytic and field studies. In S. Levy \& M. Killen (Eds.), Intergroup attitudes and relations in childhood through adulthood, 236-249. Oxford, UK: Oxford University Press.

Van Oudenhoven, J. P., Groenewoud, J. T., \& Hewstone, M. (1996). Cooperation, ethnic salience and generalization of interethnic attitudes. European Journal of Social Psychology, 26(4), 649-661. doi: 10.1002/(SICI)1099-0992(199607)26:4<649::AID-EJSP780>3.0.CO;2-T

Verkuyten, M. (2009). Self-esteem and multiculturalism: An examination among ethnic minority and majority groups in the Netherlands. Journal of Research in Personality, 43(3), 419-427. doi: 10.1016/j.jrp.2009.01.013

Voci, A., \& Hewstone, M. (2003). Intergroup contact and prejudice toward immigrants in Italy: The mediational role of anxiety and the moderational role of group salience. Group Processes and Intergroup Relations, 6, 37-54. doi: 10.1177/1368430203006001011

Vorobyov, S. M. (2001). Etnopoliticheskiye protsessy na Severnom Kavkaze v postsovetskiy period [Ethnopolitical processes in the North Caucasus in the post-Soviet period] (Unpublished doctoral dissertation)., Stavropol, Russia: Stavropol State University 
Vsesoyuznaya perepis' naseleniya 1939 goda, 1959 goda, 1970 goda, 1979 goda, 1989 goda. Natsional'nyy sostav naseleniya po regionam Rossii (2015). [All Union Population Census of 1939, 1959, 1970, 1979, 1989. National composition of the population in the Russian regions]. Demoscope Weekly, 651-652. Retrieved from http://www.demoscope.ru/weekly/ ssp/rus_nac_70.php?reg=50

Ward, C., \& Kennedy, A. (1994). Acculturation strategies, psychological adjustment, and sociocultural competence during cross-cultural transitions. International Journal of Intercultural Relations, 18, 329-343. doi: 10.1016/0147-1767(94)90036-1

Ward, C., \& Masgoret, A.-M. (2008). Attitudes toward immigrants, immigration, and multiculturalism in New Zealand: A social psychological analysis. International Migration Review, 42(1), 227-248. doi: 10.1111/j.1747-7379.2007.00119.x

Ward, C., \& Rana-Deuba, A. (1999). Acculturation and adaptation revisited. Journal of CrossCultural Psychology, 40, 422-442. doi: 10.1177/0022022199030004003

Original manuscript received November 16, 2015 Revised manuscript accepted January 25, 2015

First published online March 30, 2016 